\title{
IMPLEMENTATION OF ROAD PERFORMANCE CALCULATION MODELS USED IN STRATEGIC PLANNING SYSTEMS FOR LITHUANIA CONDITIONS
}

\section{MARTYNAS JURKEVIČIUS*, VIRGAUDAS PUODŽIUKAS, ALFREDAS LAURINAVIČIUS}

Dept of Roads, Vilnius Gediminas Technical University, Vilnius, Lithuania

Received 25 February 2020; accepted 5 June 2020

\begin{abstract}
Deficiency or inadequate allocation of road maintenance and development funds leads to total road network degradation. In order to ensure proper condition of road pavement with a limited budget, we need road maintenance optimisation for the entire road network. The road maintenance optimisation can be achieved using knowledge-based strategic planning systems. The collection and analysis of necessary data help design different road maintenance long-term strategies. The output results help select priorities for road maintenance and proper fund allocation. Optimal road maintenance strategy is the way to keep a fairly good road network with available funds. In addition, the road user costs can be reduced. The aim of this paper is to offer a road maintenance management system for Lithuanian conditions. The model will help evaluate the performance of the current road network and prepare a multi-year priority list for road works.
\end{abstract}

Keywords: HDM-4, IRI, knowledge-based strategic planning system, long-term planning, performance analysis, road maintenance, RONET.

* Corresponding author. E-mail: martynas.jurkevicius@vgtu.lt

Martynas JURKEVIČIUS (ORCID ID 0000-0003-2303-8864)

Alfredas LAURINAVIČIUS (ORCID ID 0000-0001-8520-0906)

Copyright (C) 2020 The Author(s). Published by RTU Press

This is an Open Access article distributed under the terms of the Creative Commons Attribution License (http://creativecommons.org/licenses/by/4.0/), which permits unrestricted use,

distribution, and reproduction in any medium, provided the original author and source are credited. 


\section{Introduction}

Roads make a crucial contribution to economic development and growth and bring important social benefits. Therefore, large funds are allocated to road maintenance and new road construction. However, not always the allocated funds are properly distributed to where they are needed most. Sometimes the amount of funding could be too low. Road maintenance is an integral part of each road network. Road maintenance ensures safe, continuous and comfortable road traffic at a relatively small cost. Road maintenance costs are just a few percent of road user costs. For the road maintenance funds to be distributed properly, knowledge-based road maintenance management is needed. Although the construction of new roads or rehabilitation works look very attractive, they are very costly to implement. Properly performed recurrent and periodic maintenance could drastically reduce the number of pavements strengthening works, while maintaining or even improving the existing road network condition (Burningham \& Stankevich, 2005). Even better results can be obtained by performing preventive maintenance, while the road surface is still in decent condition. Preventive maintenance is performed by doing recurrent (pothole and crack repairs) and periodic (surface treatment, thin overlays) road maintenance works (Cirilovic, Mladenovic, \& Queiroz, 2015). To get the best possible results, maintenance planning should work all nation-wide. However, planning can also be carried out at regional road maintenance companies or even at their departments (Hafez, Ksaibati, \& Atadero, 2019).

\section{Road maintenance management and optimisation}

The main goal of road maintenance management is to improve or at least maintain the current state of the road network in order to ensure continuous, safe and cost-effective vehicle traffic. The entire road management process can be divided into four main functions (Robinson, Danielson, Snaith, 1998):

- planning;

- programming;

- preparation;

- operation.

Strategic planning consists of evaluating an entire road network with collection of data to provide a macro view of the network and to help agencies and decision makers: 
- define the rational allocation of resources among networks, regions, different types of road work;

- calculate approximate quantities, costs, and benefits;

- estimate performance outcomes;

- gain insight into the impact of budget constraints;

- program road works in a rational way (Archondo-Callao, 2008).

To make planning and programming functions easier, maintenance management and strategic planning models are used. The most important functions of these models are prediction of road pavement performance and degradation over time. As one of the road performance indicators, an international road roughness index (IRI) is used in most wide-known road degradation prediction models. These models can be divided into theory-based, experiment-based, theory and experiment combined or based on expert knowledge. Most models use theory and experiment combined methods, such as World Bank HDM-4, Deighton dTIMS, Agile Assets Pavement Analyst, RONET and others. World Bank HDM-4 model predicts IRI using distress, traffic, environmental, material and road structural factors. Similarly, dTIMS also uses structural, environmental and distress factors, but it does not require traffic input into calculations (Uglova \& Saenko, 2016).

For analysis and management, the RONET (Road Network Evaluation Tools) model was selected. This model was chosen as an alternative to HDM-4 model because it was free and easily accessible, and it was much simpler and required less knowledge than the HDM-4 model, but retained a relatively accurate result. RONET is based on a simplified HDM-4 model of pavement deterioration but does not require large amounts of data, their accuracy and constant updates of the database. RONET assesses the performance of the road network over time under various road maintenance standards and different levels of funding (Mladenovic, Cirilovic, \& Queiroz, 2011; Mosianedi \& Hassan, 2014; Queiroz, 2013).

RONET sets the optimum standard of road maintenance for each road or homogenous group of road sections and determines the funding level characterised by difference between current and required maintenance costs (Mladenovic et al., 2011). Due to its simplicity and low operating costs (based on requirements for financial and constant data updates), RONET could be useful not only for nation size network but also for small district-based road agencies (Hafez et al., 2019). 


\section{Current situation in Lithuania}

For determining overall road surface condition on asphalt or concrete roads, Lithuania uses the methodology "Performance Indicators for Road Pavements" developed by COST Action 354.

General performance index (GPI) can be calculated combining three different indices (Lithuanian Road Administration, 2018):

- safety index - assesses the impact of individual condition indices expressed by weighting factors on ride safety;

- comfort index - assesses the impact of individual condition indices expressed by weighting factors on ride comfort (quality);

- structural index - assesses the structural properties of the road construction layers.

For the calculations of particular indices, the values of these parameters are used:

- average road roughness (IRI);

- transverse evenness (RUT);

- road texture (MPD);

- cracking (TP_PL);

- $\quad$ surface defects (TP_PD);

- surface defects-bituminous bleeding (TP_PD*).

Calculations of general performance index cover only asphalt and concrete pavement roads but not gravel roads. In Lithuania, there are still roughly $6000 \mathrm{~km}$ of gravel roads (the whole national road network consists of $21400 \mathrm{~km}$ ). The main focus in the past few years was to pave gravel road sections with asphalt (Lithuanian Road Administration, 2014, 2015; Morkūnas, Vilkelis, Skrinskas, Skrodenis, \& Žilionienè, 2015). For those gravel roads that will not get asphalt pavement in the near future recurrent maintenance works are performed. Currently no evaluation of gravel layer loss of thickness or any other similar gravel road condition evaluation is performed.

Knowledge of overall condition of particular road sections in the network help create priority lists for periodic maintenance and rehabilitation works. However, road work priority listing does not solve long-term problems of maintaining acceptable conditions of road network. As a solution, knowledge-based strategic planning should be implemented. 


\section{Implementation of long-term road maintenance planning}

\subsection{Asphalt and concrete pavement roads}

RONET model for asphalt and concrete pavements uses a simplified HDM-4 model of road degradation (Archondo-Callao, 2009):

$$
\begin{aligned}
\mathrm{d} I R I= & K_{g p}\left[\left(a_{0} \cdot \exp \left(K_{g m} \cdot m \cdot A G E_{3}\right)\left(1+S N C \cdot a_{1}\right)^{-5} Y E 4+a_{2} \cdot A G E_{3}\right)\right] \\
& +\left(K_{g m} \cdot m \cdot R I_{a}\right),
\end{aligned}
$$

where $\mathrm{d} I R I$ - annual road roughness change (International Roughness Index, IRI), $\mathrm{m} / \mathrm{km} ; K_{g p}-$ a calibration factor of roughness progression; $K_{g m}$ - a calibration factor for environmental coefficient; $a_{i}$ - layer coefficients; $m$ - an environmental coefficient; $A G E_{3}$ - pavement age since last overlay, reconstruction or new construction, years; $S N C$ - a modified structural number of pavement during construction, reconstruction, or last rehabilitation; YE4 - an annual number of equivalent standard axles, million ESA per lane per year; $R I_{a}$ - roughness at the start of the analysis year (IRI), $\mathrm{m} / \mathrm{km}$.

The model coefficients and calibration factors can be left recommended by the HDM-4 model or selected individually in order to ensure accuracy of results. More accurate coefficients and calibration factors may be obtained overtime by doing research and comparing HDM model predictions with measures of road performance factors (Thube, 2013).

RONET computes the network road user costs for different maintenance and rehabilitation standards at the performance assessment module. Road users' costs are calculated using HDM-4 based RUCKS model:

$$
R U C=a_{0}+a_{1} I R I+a_{2} I R I^{2}+a_{3} I R I^{3},
$$

where RUC - road users' costs, EUR per veh. per km; $a_{i}$ - RONET used cost model coefficients based on a particular country.

Road users' costs show what losses road users suffer depending on the road surface condition.

RONET model establishes seven different standards of road maintenance. "Very high" standard presents a scenario without budget constraints with a high level of recurring and rehabilitation works. "High", "Medium", "Low" and "Very low" standards present a scenario with lower road maintenance costs corresponding to each 
standard. "Minimum" standard presents a scenario where only the road reconstruction is performed when very high IRI is reached. In this scenario none of the pavement strengthening or periodic maintenance of road works are done. Maintenance standards were based on the Lithuanian Road Maintenance Standard Specifications (RMSS) (Table 1).

Table 1. The maximum road roughness (IRI)

\begin{tabular}{cccc}
\hline \multirow{2}{*}{ Road type } & \multicolumn{3}{c}{ Maintenance level } \\
\cline { 2 - 4 } & I - High & II - Average & III - Low \\
\cline { 2 - 4 } National roads & $2.5 \mathrm{~m} / \mathrm{km}$ & $3.0 \mathrm{~m} / \mathrm{km}$ & $3.5 \mathrm{~m} / \mathrm{km}$ \\
Regional roads & $3.5 \mathrm{~m} / \mathrm{km}$ & $4.0 \mathrm{~m} / \mathrm{km}$ & $4.5 \mathrm{~m} / \mathrm{km}$ \\
\hline
\end{tabular}

For each road depending on the pavement condition and traffic volume using RONET, the aforementioned standards of maintenance were assessed and optimal scenario was obtained, which ensured the lowest road users' and road maintenance costs. The programme also provides two higher quality maintenance scenarios ("Optimal +1 " and "Optimal +2 "), and three low-quality scenarios ("Optimal -1 ", "Optimal -2 " and "Optimal -3 ").

In order to develop a road maintenance strategy using RONET model, data from these factors were collected for the entire road network:

- pavement type;

- average annual daily traffic;

- road element parameters;

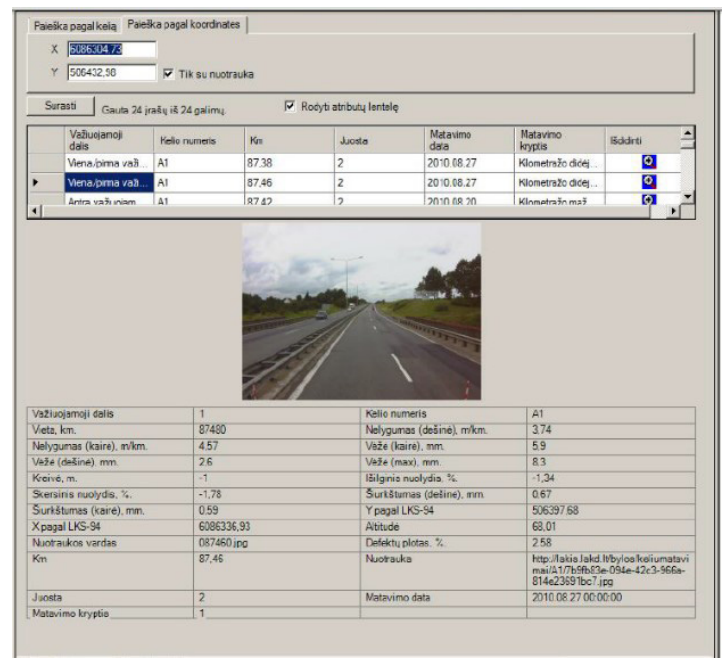

Figure 1. LAKIS road measuring application user interface (LAKIS, n. d.) 
- road roughness (IRI);

- pavement age;

- average costs of different road works;

- historical expenditures.

The above-mentioned parameters were obtained from the Lithuanian Road Information System (LAKIS, n. d.) and visual inspection. LAKIS user interface is presented in Figure 1.

After collecting all the data required for calculation, a road network was divided into separate road sections which were grouped into homogeneous sections. Sections were divided according to the following criteria:

- road type (national or regional);

- road pavement type;

- the date of last repair (reseal, rehabilitation or reconstruction);

- average annual daily traffic (AADT);

- road roughness (IRI).

The entire road network was divided into road sections. Suitable road sections were divided into homogeneous groups of road sections according to the above-mentioned criteria.

The calculations lad to seven different road maintenance scenarios.

The "Optimal" road maintenance scenario provides the lowest society costs compared to other scenarios, and the road agency costs are the lowest ones of all scenarios.

Two strategies that provide higher standards of maintenance ("Optimal +1" and "Optimal +2") ensure a better overall network condition, but at higher maintenance costs. Lower standard strategies ("Optimal -1", “Optimal -2", “Optimal -3") require more investment into maintenance and higher costs to road users.

"Optimal", "Optimal +1 " and "Optimal +2 " strategies reduce road user costs, which increase with the road roughness. Better road condition reduces vehicle operating costs, the environmental pollution and improves passenger comfort.

In "Optimal" and higher standard scenarios, significantly lower amounts of pavement strengthening and much periodic maintenance work are required. It is therefore concluded that when these scenarios are implemented, the road condition is maintained stable without a loss of full bearing capacity. "Optimal -1 " and lower standard maintenance scenarios require much rehabilitation work. In the scenario "Minimum", there is a total absence of periodic maintenance, as only road reconstruction is carried out when road pavement reaches a critical condition. A critical condition of road is considered to be when $I R I>6 \mathrm{~m} / \mathrm{km}$ (Lithuanian Road Administration, 2018). 


\subsection{Gravel roads}

Using RONET (or any other HDM based planning system), it is also possible to calculate the gravel layer loss of thickness for unpaved roads.

Model for gravel loss is shown in Eq. (3) (Archondo-Callao, 2009):

$M L A=365 K_{g i}\left(3.46+2.46 M M P \cdot R F \cdot 10^{-4}+K T \cdot A A D T\right)$,

where $M L A$ - the predicted annual material loss, mm per year; $R F$ - average rise plus fall of the road, $\mathrm{m} / \mathrm{km}$; $M M P$ - mean monthly precipitation, mm per month; $A A D T$ - annual average daily traffic, veh. per day; $K T$ - the traffic-induced material whip-off coefficient; $K_{g i}$ - the gravel material loss calibration factor.

Using the gravel loss model, it can be predicted for how many years the current gravel road structure will last. Based on the value of MLA, the layer thickness of new material can be selected depending on how long the new layer should last.

\section{Surface treatment}

Surface treatment application is one of the ways to repair the road surface. It is a cost-effective type of work, which can help maintain the road condition for several years. In RONET (HDM also uses a similar equation), the roughness after a surface treatment was computed by the following equation (Archondo-Callao, 2009):

$$
R I_{a w}=R I_{b w}-\max \left(0, \min \left(0.3 R I_{b w}-5.4\right), 0.5\right),
$$

where $R I_{a w}$ - roughness after surface treatment (IRI), m/km; $R I_{b w}-$ roughness before surface treatment (IRI), $\mathrm{m} / \mathrm{km}$.

In Lithuania when surface treatment works are carried out, also rough spots milling and levelling layer application works are done. The above-mentioned formula does not calculate the effect for road roughness after levelling layer installation; therefore, in order to get more accurate results Eq. (4) was adjusted.

Surface treatment application was divided into two parts: a levelling layer installation and the application of surface treatment. Installed levelling layer was taken as a new layer. Thickness of the layer was adopted based on amount of materials used on previous surface treatment works. Roughness levelling layer was taken as $20 \mathrm{~mm}$ thick and in calculation it was used as a new layer.

For that reason another formula, which calculated road roughness after pavement strengthening by installing a new layer of asphalt, was used (Archondo-Callao, 2009): 
$R I_{a w}=2.0+0.01 \cdot \max \left(0,\left(R I_{b w}-2.0\right) \cdot \max \left[0,\left(80-O V_{t h}\right)\right]\right)$,

where $R I_{a w}$ - roughness after new layer installation (IRI), m/km; $R I_{b w}-$ roughness after new layer installation (IRI), $\mathrm{m} / \mathrm{km} ; O V_{t h}-$ thickness of a new asphalt layer, $\mathrm{mm}$.

Road roughness change after surface treatment with levelling layer installation was calculated by combining Eqs. (4) and (5):

$$
\begin{aligned}
R I_{a w}= & \left(2.0+0.01 \cdot \max \left[0,\left(R I_{b w}-2.0\right) 60\right]\right) \\
& -\max \left(0, \min \left(0.3\left[\left(2.0+0.01 \cdot \max \left[0,\left(R I_{b w}-2.0\right) 60\right]\right)-5.4\right], 0.5\right)\right) .
\end{aligned}
$$

RONET model was adjusted by changing formula (4) for roughness calculation after surface treatment to formula (6). All calculations were executed with the new formula in the model.

Differences between Eqs. (4) and (6) of road roughness (IRI) calculation after surface treatment with a levelling layer are shown in Table 2.

Table 2. Calculated road roughness predictions after surface treatment

\begin{tabular}{|c|c|c|}
\hline \multicolumn{3}{|c|}{ Roughness (IRI), m/km } \\
\hline Initial & Calculated using Eq. (3) & Calculated using Eq. (5) \\
\hline 3.0 & 3.0 & 2.6 \\
\hline 4.0 & 4.0 & 3.2 \\
\hline 5.0 & 5.0 & 3.8 \\
\hline 6.0 & 5.82 & 4.4 \\
\hline 6.5 & 6.17 & 4.7 \\
\hline
\end{tabular}
with levelling layer works

As mentioned before, the thickness of levelling layer is based on the amount of materials used to do surface treatment works, and it is equal to $20 \mathrm{~mm}$. As shown in Table 2, Eq. (4) does not evaluate the effect of a levelling layer on road roughness. When an initial IRI value before road works is $5.4 \mathrm{~m} / \mathrm{km}$ or lower, the change of IRI after surface treatment works equals 0. Whereas results of calculations done using Eq. (6) show IRI change of up to $28 \%$ compared to initial IRI.

The new equation allows achieving more relevant and accurate road roughness change calculation results after surface treatment with levelling layer works. However, to get more accurate results further research is needed in which the dependency of road surface parameters before and after road works could be analysed. 


\section{Conclusions}

The article presented road performance calculation models used in strategic planning for the road network.

1. Road maintenance management is beneficial for both the monitoring and evaluation of the current condition of the road network and the planning of road maintenance. Road maintenance management allows for proper distribution of limited financial resources.

2. The evaluation of current state of the road network and creation of priority lists are not enough to effectively maintain a long-term good condition of the network. For that reason, knowledge-based strategic planning should be executed.

3. HDM road roughness equation after surface treatment application (Eq. 4) was adjusted to estimate the effect of an additional levelling layer of asphalt.

4. The adjustment of Eq. (6) leads to more accurate results of road roughness calculation.

5. The further research will analyse the probability of adaptation of Eq. (6) for technology of surface treatment with a levelling layer.

6. RONET model is an appropriate tool for both regional road maintenance companies and national road agencies to assess the current condition of the roads (asphalt, concrete, gravel) and plan maintenance work for several years in front.

\section{REFERENCES}

Archondo-Callao, R. (2008). Applying the HDM-4 Model to Strategic Planning of Road Works. Transport Papers. The World Bank, 77 p. Retrieved from http://siteresources.worldbank.org/INTTRANSPORT/Resources/3362911227561426235/5611053-1229359963828/tp-20.pdf

Archondo-Callao, R. (2009). HDM-4 Road User Cost Model Documentation, Version 1.20, User's Guide. The World Bank.

Burningham, S., \& Stankevich, N. (2005). Why road maintenance is important and how to get it done. Transport Notes, TRN-4, 33925, 1-10. The World Bank, Washington, DC. Retrieved from http://siteresources.worldbank. org/INTTRANSPORT/Resources/336291-1227561426235/5611053 1231943010251/TRN4_Road_Maintenance.pdf

Cirilovic, J., Mladenovic, G., \& Queiroz, C. (2015). Implementation of preventive maintenance in network-level optimization: case study of the Serbian low-volume road network. Transportation Research Record: Journal of the Transportation Research Board, 2473, 49-55.

https://doi.org/10.3141/2473-06 
Hafez, M., Ksaibati, K., \& Atadero, R. (2019): Pavement maintenance practices of low-volume roads and potential enhancement: the regional experience of Colorado pavement management system. International Journal of Pavement Engineering. https://doi.org/10.1080/10298436.2019.1643021

LAKIS (Information System of National Significance roads). (n. d.). Retrieved from https://lakis.lakd.lt/

Lithuanian Road Administration under the Ministry of Transport and Communications. (2015). 2015-2020 metų Lietuvos Respublikos valstybinès reikšmès kelių priežiūros ir plètros programa [Roads Maintenance and Development Program for National Roads of the Republic of Lithuania].

Lithuanian Road Administration under the Ministry of Transport and Communications. (2014). Kelių priežiūros vadovas KPV PN-14 [Road Maintenance Guideliness].

Lithuanian road administration under the Ministry of Transport and Communications. (2018). Valstybinès reikšmès kelių dangos būklès vertinimo aprašas [Performace Evaluation of National Significance Roads].

Mladenovic, M., Cirilovic, J., \& Queiroz C. (2011). Optimization of Road Maintenance and Rehabilitation on Serbian Toll Roads. In Eighth International Conference on Managing Pavement Assets (pp. 1-9), Chile, Santiago.

Morkūnas, E., Vilkelis, A., Skrinskas, S., Skrodenis, E., \& Žilionienė, D. (2015). Strategic road maintenance and development programme of the republic of Lithuania for 2030 - A tool for using national funds to create a sustainable and viable road network. The Baltic Journal of Road and Bridge Engineering, 10(3), 1-9. https://doi.org/10.3846/bjrbe.2015.35

Mosianedi, T., \& Hassan, M. (2014). Pavement management analysis in South Africa using RONET: the case of Free State Province. ARRB Group Limited.

Queiroz, C. (2013). RONET: Road Network Evaluation Tools. Retrieved from https://fenix.tecnico.ulisboa.pt/downloadFile/3779579678007/Palestra_ CesarQueiroz_9abr-2013_2.pdf

Robinson, R., Danielson, U., Snaith, M. S. (1998). Road Maintenance Management - Concepts and Systems. Macmillan press, London, 291 p. https://doi.org/10.1007/978-1-349-14676-5

Thube, D. T. (2013). Highway Development and Management Model (HDM-4): calibration and adoption for low-volume roads in local conditions. International Journal of Pavement Engineering, 14(1), 50-59. https://doi.org/10.1080/10298436.2011.606320

Uglova, E. V., \& Saenko, S. S. (2016). Review of longitudinal pavement roughness prediction tools. Russian journal of transport engineering, 3(4), 1-13. https://doi.org/10.15862/05angTS416 